\title{
Effects of Service Quality on Customer Loyalty-A Case of Taiwanese Watson's Personal Care Stores
}

\author{
Yu-Je Lee ${ }^{1, *}$, Peng-Hsiang Kao ${ }^{2}$ \\ ${ }^{1}$ Takming University of Science and Technology, Taiwan \\ ${ }^{2}$ China University of Science and Technology, Taiwan
}

Copyright (C) 2015 Horizon Research Publishing All rights reserved.

\begin{abstract}
This study is primarily intended to verify the effects of service quality on the customer loyalty using the customer satisfaction as a mediator. Focus on the population of Taiwan's Watsons Personal Care Stores, a total of 395, to adopt a Stratified Random Sampling for sampling with totally sending out 850 copies of mailed questionnaires with a receipt of 228 copies valid response questionnaires for a $26.82 \%$ effective response rate, and applying a Structural Equation Modeling (SEM) to verify whether the goodness-of-fit of Overall Model, Structural Model and Measurement Model can be established in this study. The results have been found: (1) Making positive effects on the customer satisfaction; (2) Customer satisfaction making significant and positive effects on the customer loyalty; and (3) Excellent service quality making positive but not significant effects on the customer loyalty. Based on the results, the customer satisfaction has an approximately complete mediating effect. Additionally, the study results can not only provide businesses with the knowledge about the significance and generated benefits of service quality and customer satisfaction, but also make a reference for relevant business decision-making. Briefly, it is expected that the study results will provide businesses with effective applications of the service quality and customer satisfaction to enhance the customer loyalty increasing customers' repurchase intention.
\end{abstract}

Keywords Service Quality, Customer Satisfaction, Customer Loyalty

\section{Background (Motives and Purposes) of this Research}

Along with the rising awareness of public health and emerging beauty industries, drug \& cosmetic stores have been everywhere in our daily life that they have become an essential industry. Watsons Personal Care Store, formerly Watsons pharmacy, a chain retailer of personal care products in Asia, affiliated to Hutchison Whampoa Watsons Group, which is the largest personal care and beauty retail chain stores in Asia and Europe, operation across 12 Asian and European markets, including Taiwan $10 \& 36$. Taiwan Watsons officially opened in 1987 , now the very fast store expansion has been achieved to have more than 400 stores across the whole island. Meanwhile, professional pharmacists and beauty consultants are posted in every store, and enthusiastic staff with friendly, professional and caring brand DNA offer customers the most convenient, full-range and professional shopping options of personal care products.

In regard of service quality and customer satisfaction being important factors for the enhancement of customer loyalty, Michael ${ }^{24}$ manifested 'a causal relationship and interdependence between service qualities, customer satisfaction and customer loyalty, necessarily seen as a whole for evaluation and management'. For all companies, important issues for running a business are meeting customer's needs and making them satisfied. Nevertheless, many researches pointed out, higher customer satisfaction will enhance customer loyalty; next, the enhancement of customer loyalty will contribute to make profits for the business and facilitate the company's growth; therefore, the enhancement of customer satisfaction is very important, and customer loyalty can't be overlooked by the companies ${ }^{21}$. However, in the knowledge economy era, those who can master the service quality for customers, and their satisfaction will grasp the competitive advantages, further enhance their loyalty, which has been one of current key issues worth researching. Hence, this study wants to verify and explore the effects of service quality on customer loyalty, using customer satisfaction as a mediator, and focus on the population of Taiwan's Watsons Personal Care Stores. Therefore, the main purpose of this study consists of three points as follows:

(1) To verify whether excellent service quality of Taiwan's Watsons Personal Care Stores makes positive and significant effects on customer satisfaction.

(2) To verify whether the customer satisfaction of Taiwan's Watsons Personal Care Stores makes positive and 
significant effects on customer loyalty.

(3) To verify whether excellent service quality of Taiwan's Watsons Personal Care Stores makes positive and significant effects on customer loyalty.

\section{Literature Review}

In regard of the main dimensions of this research including Literature Review of service quality, customer satisfaction and customer loyalty, herewith, respective discussions are made as below:

\subsection{Service Quality}

\subsubsection{Definitions and Dimensions of the "Service Quality"}

There are many literatures related to service quality researches. This research has quoted the 'Conceptual Definition' from Lin ${ }^{22}$, that is, 'The service quality consists of customer's expectation for service and customer cognition after actually serviced, and the difference between both indicates good or bad service quality'. As for the "Operational Definition" of service quality in this study, it referred to five dimensions of service quality proposed by Parasuraman, Zeithaml, and Berry ${ }^{31}$ : (1) Tangibles: supply of service physical facilities, equipment and service staff appearance; (2) Reliability: ability to reliably and correctly fulfill the commitments to consumers ; (3) Responsiveness: willingness to assist customers and ability to provide fast service; (4) Assurance: service staff's knowledge and manners, and their ability to have customers depended; and assured (5) Empathy: ability to provide customers with care and concerns.

Focus on the "service quality" basic concepts quoted from relevant literature, here is a brief explanation as below:

Previous literature about service quality mainly stressed on the production activities in the manufacturing industries, and the discussion focused on the concepts of physical goods. For example, Juran ${ }^{16}$ classified service quality into five parts: (1) internal qualities; (2) hardware qualities; (3) software qualities; (4) time promptness; (5) psychological qualities. It has been until Parasuraman, Zeithaml, and Berry $^{29}$ inferred 'the concepts of service quality from physical product quality', who defined service quality as "the difference between customer's expectation for service and real perception of service after actually receiving service"; meanwhile, Parasuraman, Zeithaml, and Berry ${ }^{30}$ further pointed out 'three features of service quality respectively: (1) It's more difficult to evaluate service quality than physical goods; (2) Perception of good or bad service quality comes from the difference between customer's expectation level and actual perception levels of service; (3) The measuring method of service quality does not only depend on service results, but also include measurement of the service delivery process'. Secondly,
$\mathrm{Lin}^{22}$ considered 'the service quality as an evaluation from customers for advantage and disadvantage degrees of the whole service'. Service quality consists of customer's expectation for service and customer cognition after actually serviced, and the difference between both indicates good or bad service quality.

Additionally, Parasuraman et al ${ }^{31}$ also redefined 'service quality as "advantage and disadvantage degrees of the service generated from the interaction between service providers and customers during the service delivery process", meanwhile, a SERVQUAL Scale was proposed, which made total five dimensions respectively: (1) tangibles; (2) reliability; (3) responsiveness; (4) assurance; and (5) empathy'. As a result, the SERVQUAL (SERVICE QUALITY) Scale is currently the most widely used in the measurement of service quality, which comprises five dimensions with excellent reliability, validity and low repetition, and twenty-two items for measuring service quality. It is the reason why this study quoted 'the five dimensions of SERVQUAL Scale', proposed by Parasuraman et $\mathrm{al}^{31}$, as a measurement dimension in this study.

\subsection{Definitions and Dimensions of the Customer Satisfaction}

"The conceptual definition of "customer satisfaction" in this study quoted the definition' made by Huang, Tsai, and $\mathrm{Xu}^{14,}$ which referred to "customer satisfaction is built upon consumers' expectation toward products before purchase, and their cognition of product performance after purchase, which will show the difference to indicate satisfaction or dissatisfaction. The dissatisfaction occurs when the product performance can't achieve expectation; in contrast, satisfaction occurs when the product performance is successful beyond expectation". Regarding the measurement dimension for customer satisfaction in this study, it followed 'three of the dimensions' made by Zeithaml \& Binter $^{40}$ : (1) product quality; (2) service quality; and (3) price for research.

In regard of basic concepts of definition and dimension for the above customer satisfaction, they were summarized from the following literature.

As for the definition of customer satisfaction, Cardozo ${ }^{3}$ manifested 'the customer's satisfaction will increase the behavior of repurchase, other products will be purchased, too'. 'Customer satisfaction is the evaluation result including the evaluation of giving and acquiring, ${ }^{28}$, and such a satisfaction also encompasses cognitive or emotional elements ${ }^{26}$. Spreng ${ }^{34}$ considered 'customer satisfaction meaning consumers' evaluation of the purchase process after they have bought the products, generating the sensible and rational perception state'. In comparison with grabbing new customers, the relationship can be set up between customer's satisfaction and old customers, which is a cost-saving way to get old customers' higher propensity 
for repurchase; meanwhile, 'grabbing new customers by positive word-of-mouth marketing makes significant effects on profitability' ${ }^{39}$. Singh ${ }^{32}$ discovered 'something from social psychology and organizational theories that Satisfaction is a multiple-facet dimension with multiple items for measuring the degree of satisfaction, and to indicate the measurement of customer satisfaction making a variation due to different industries or research subjects'. Ostrom \& Iacobucci $^{28}$ considered 'the evaluation of customer satisfaction as customer's expectation for products or services, and the degree of Satisfaction Judgment generated from cognitive performance, i.e., the customer overall evaluation toward product prices offered by the companies, their internal operational efficiency and service systems, employees' service attitude and professional knowledge, the companies' overall performance and the proximity to an ideal company, and so on'.

Zeng ${ }^{41}$ held 'an opinion that customer satisfaction is the interaction between service staff and customers, more smooth interaction, higher customer satisfaction'.

$\mathrm{Lu}^{23}$ pointed out customer satisfaction is a formation of consumption attitude; exactly, consumers make the overall evaluation after purchasing products or receiving services.

Huang et $\mathrm{al}^{14}$ manifested 'customer satisfaction is built upon consumers' expectation toward products before purchase, and their cognition of product performance after purchase, which will show the difference to indicate satisfaction or dissatisfaction. The dissatisfaction occurs when the product performance can't achieve expectation; in contrast, satisfaction occurs when the product performance is successful beyond expectation'.

As for the dimensions of customer satisfaction in this study, they referred to the following relevant literature:

Singh $^{32}$ discovered 'something from social psychology and organizational theories that Satisfaction is a multiple-facet dimension certainly with multiple items for measuring the degree of satisfaction, further to indicate the measurement of customer satisfaction making a variation due to different industries or research subjects'.

Ostrom and Iacobucci ${ }^{28}$ proffered 'the measuring items of consumer satisfaction encompass product price, service efficiency, service staff attitude, company overall performance, the proximity to an ideal company, and so on'. Wiley ${ }^{38}$ also proposed 'consumer satisfaction contains: (1) product quality; (2) product delivery speed; (3) sales staff knowledge; (4) friendly service; (5) after-sale service; (6) competitiveness of product prices; (7) values; (8) degree of satisfaction; (9) probability of repurchase for similar products; and (10) timely service'.

Zeithaml \& Binter ${ }^{40}$ proffered 'the dimensions of overall satisfaction, (1) product quality; (2) service quality; (3) situational factors; (4) personal factors; and (5) prices'. Westbrook $^{37}$ presented 'the measurement dimension of satisfaction, (1) sales staff satisfaction; (2) store environment satisfaction; and (3) product satisfaction'. Chung $^{8}$ explored 'the relationship of customer satisfaction between different E-shop types, bringing up its consumer satisfaction dimensions divided into online satisfaction and brand satisfaction'.

\subsection{Definitions and Dimensions of the Customer Loyalty}

The conceptual definition of "customer loyalty" in this study quoted 'the definition' made by Heskett ${ }^{13}$, which referred to "customer loyalty means that customers repurchase, commit themselves to introduce the company's products or service, willingly convince others using the company's products or service, voluntarily recommend the company's products or willingly help improve the company's service, and so on". The measurement dimension for customer loyalty in this study, it followed the 'perspectives' from Griffin ${ }^{11}$, two dimensions of "preference" and "repetitive support". Regarding conceptual definition of customer loyalty, it is inspired by the following literature.

Oliver ${ }^{25}$ considered 'customer loyalty will be affected by external environment or tempted by other marketing tactics'. Nevertheless, customers' favorite products or service in future purchase and commitment will neither be affected nor changed'. Besides, Oliver ${ }^{27}$ also followed 'faith, attitude, and intention mode to classify the loyalty into four stages including cognitive loyalty, emotional loyalty, behavioral \& intentional loyalty, and action loyalty'.

Bhote $^{2}$ pointed out 'customer loyalty is customers being satisfied with the company's merchandise or service that they would like to promote the company's products'.

Oliver ${ }^{25}$ believed 'customer loyalty refers to potential conversion behavior probably triggered by environmental effects or marketing tactics though; customers' favorite merchandise or service, future repurchases and commitment to frequent patronage won't be changed easily'.

Heskett ${ }^{13}$ also manifested 'customer loyalty means customers' repurchases, commitment to introduce the company's products or service to others, willingness of convincing others to use the company's products or service, voluntary recommendation to the company's products, or willing assistance to improve its service, and so on'.

Sirdeshmukh and Saboll $^{33}$ considered 'customer loyalty means customers may want to maintain the relationship with the current company, therefore, they probably adopt various behaviors, including increased usage of one certain supplier's products, praising such a company and repurchases'. Griffin ${ }^{11}$ considered 'the second factor' to decide whether the customer is loyal toward products or service other than "Preference", is "Repetitive Support". Thence, these two dimensions were applied to divide loyalty into four types: (1) high loyalty: relatively high preference and highly repurchases; (2) potential loyalty: relatively high preference and low repurchases; (3) dull loyalty: relatively low preference and highly repurchases; and (4) lacking loyalty: relatively low preference and low repurchases. 


\subsection{Relevant Literature to Service Quality and Customer Satisfaction}

Concerning the relevance between service quality and customer satisfaction, this study summed up the following literature to make the hypothesis as below: $\mathrm{H}_{1}$ : Whether the excellent service quality of Taiwan's Watsons Personal Care Stores can make positive effects on customer satisfaction or not.

Taylor \& Baker ${ }^{35}$ considered 'service quality will affect customer satisfaction, as well as affect customer's purchase behavior'.

Hurley \& Estelami ${ }^{15}$ considered 'the dimension of service quality is different from the one of Satisfaction, meanwhile, they also believed service quality is an antecedent factor for customer satisfaction'.

The research of Chen and Wang' discovered 'the expectation for service quality has direct and positive correlation to customer satisfaction'.

The research of $\operatorname{Lin}^{19}$ manifested 'service quality and customer satisfaction can effectively predict the Loyalty'.

Huang et al ${ }^{14}$ believed 'service quality makes significantly positive effects on customer satisfaction'.

With an overview of previous descriptions, although research subjects in each literature are different from this study, the above Hypothesis $1\left(\mathrm{H}_{1}\right)$ proposed by this study, i.e. excellent service quality of Taiwan's Watsons Personal Care Stores makes positive and significant effects on customer satisfaction, necessarily in use of interview surveys and statistical methods to verify whether the hypothesis substantiated or not.

\subsection{Relevant Literature to Customer Satisfaction and Customer Loyalty}

Concerning the literature of relevance between customer satisfaction and customer loyalty, this study summed up the following literature to make the hypothesis as below: $\mathrm{H}_{2}$ : the customer satisfaction of Taiwan's Watsons Personal Care Stores makes positive and significant effects on customer loyalty.

$\mathrm{Lin}^{21}$ believed 'higher customer satisfaction will enhance customer loyalty, while enhanced customer's loyalty is helpful to creating profits for the businesses, and promoting the growth of the company'.

The research of Lee and $C h n^{18}$ pointed out 'significant relevance exists between these two dimensions of customer satisfaction and customer loyalty'.

Lin and $\mathrm{Lee}^{20}$ considered 'customer satisfaction will make positive effects on customer loyalty'.

Huang et $\mathrm{al}^{14}$ considered 'customer satisfaction makes significantly positive effects on customer loyalty'.

With an overview of previous descriptions, although research subjects in each literature are different from this study, the above Hypothesis $2\left(\mathrm{H}_{2}\right)$ proposed by this study, i.e. customer satisfaction of Taiwan's Watsons Personal Care Stores makes positive and significant effects on customer loyalty, necessarily in use of interview surveys and statistical methods to verify whether the hypothesis substantiated or not.

\subsection{Relevant Literature to Service Quality and Customer Loyalty}

Concerning the relevance between service quality and customer loyalty, this study summed up the following literature to make the hypothesis as below: $\mathrm{H}_{3}$ : the excellent service quality of Taiwan's Watsons Personal Care Stores makes positive effects on customer loyalty.

The research of Kao ${ }^{17}$ indicated that 'service quality and customer loyalty indeed exist positive correlation'.

Chen et $\mathrm{al}^{5}$ believed 'customer satisfaction makes direct and positive effects on customer loyalty, and service quality making indirect and positive effects on customer loyalty via customer satisfaction'.

Chih, Chiu, and Lin considered 'service quality doesn't make significantly direct effects on customer loyalty; instead, making indirect effects on customer loyalty via customer satisfaction'.

With an overview of previous descriptions, although research subjects in each literature are different from those of this study, the above Hypothesis $3\left(\mathrm{H}_{3}\right)$ proposed by this study, i.e. the excellent service quality of Taiwan's Watsons Personal Care Stores makes positive and significant effects on customer loyalty, necessarily in use of interview surveys and statistical methods to verify whether the hypothesis substantiated or not.

\subsection{Research Framework}

According to the described study purposes, hypotheses and literature review as above, the following research framework can be achieved as the Figure 1: 


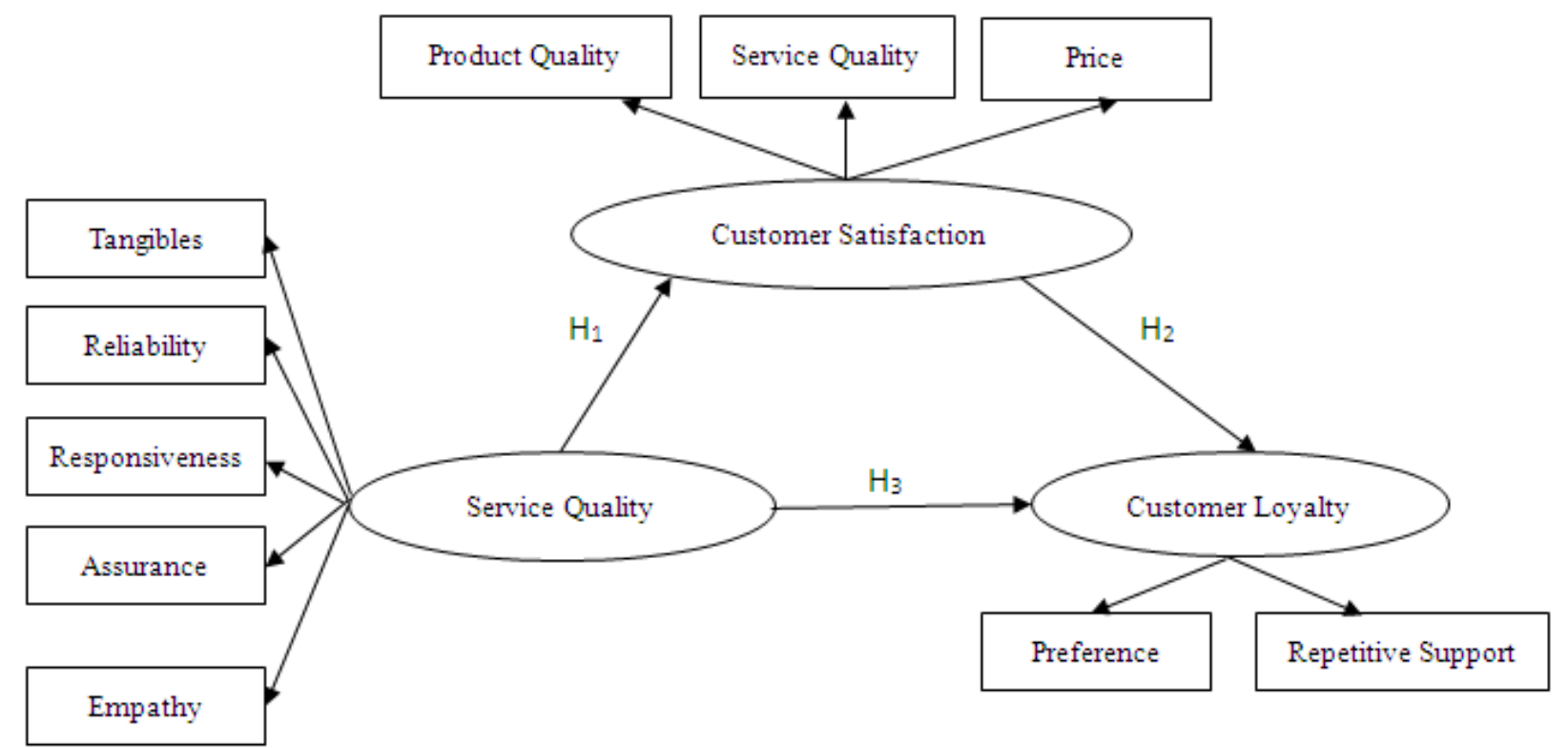

Figure 1. Research Framework

\section{Research Method}

\subsection{Research Subjects and Questionnaire Design}

Front line employees of all Taiwan's Watsons Personal Care Stores, a total of 395 as Population - (Keelung 6 Taipei 81,Taipei County 74, Taoyuan 37, Hsinchu 13, Yilan County 6, Taichung 46, Nantou 7, Chiayi 7, Changhua 11, Miaoli 7, Hualien 5, Tainan 28, Kaohsiung 49, Pingtung 15, Taitung 1, Penghu 2) throughout the 19 counties of the island in 2014, were selected to be subjects of this study, adopting the Stratified Random Sampling for testing. To enhance the content validity and reliability of questionnaires, thereby, questionnaires were given out to experts in a pilot-test before working on respective questionnaires, and the Pilot test implemented next to modify or exclude inappropriate questions of the questionnaires. Eventually, the Post-test was operated, totally sending out 850 copies of mailed questionnaires with a receipt of 228 copies valid response questionnaires for a $26.82 \%$ effective response rate. The structure table of questionnaire question numbers for variables within the main construct (Conceptual Dimension) and sub-constructs (Operational Measurement Dimension) was shown as Table 1.

\subsection{The Data Obtained from Questionnaire and Measurement Model}

To validate the research framework, this study uses SEM (structural equation modelling) for a confirmatory factor analysis (CFA). The questionnaire was constructed on the basis of three latent variables (i.e., service quality, customer satisfaction and customer loyalty), each divided into observable/explicit sub-variables that contain several questions. The data collected was processed to create a primary file for the questionnaire. As for the establishment of measurement model, this study designed the questionnaire by way of multi-dimension measurement but adopted the "dual measurement method 'to ensure successful data processing by computer software ${ }^{6}$. Table 1 shows the number of questions under each implicit and explicit variable, along with the referential sources.

Table 1. Structure of No. of Questions

\begin{tabular}{|c|c|c|c|}
\hline $\begin{array}{c}\text { Main } \\
\text { Construct }\end{array}$ & $\begin{array}{c}\text { Sub-construct or } \\
\text { measurement } \\
\text { indicators } \\
\end{array}$ & $\begin{array}{c}\text { No. of } \\
\text { questions }\end{array}$ & $\begin{array}{l}\text { References of } \\
\text { questionnaire }\end{array}$ \\
\hline \multirow{5}{*}{$\begin{array}{l}\text { Service } \\
\text { Quality } \\
\text { (SQ) }\end{array}$} & Tangibles & 2 & \multirow{5}{*}{$\underset{31}{\text { Parasuraman et al }}$} \\
\hline & Reliability & 2 & \\
\hline & Responsiveness & 2 & \\
\hline & Assurance & 2 & \\
\hline & Empathy & 2 & \\
\hline \multirow{3}{*}{$\begin{array}{l}\text { Customer } \\
\text { Satisfaction } \\
\text { (CS) }\end{array}$} & Product Quality & 2 & \multirow{3}{*}{ Zeithaml\& Binter ${ }^{40}$} \\
\hline & Service Quality & 2 & \\
\hline & Price & 2 & \\
\hline \multirow{2}{*}{$\begin{array}{l}\text { Customer } \\
\text { Loyalty } \\
\text { (CL) }\end{array}$} & Preference & 2 & \multirow{2}{*}{ Griffin $^{11}$} \\
\hline & Repetitive Support & 2 & \\
\hline
\end{tabular}

\subsection{Linear Structural Model}

This study conducted a CFA, an analytical approach contrary to the Exploratory Factor Analysis (EFA), on each pair of the three main dimensions (i.e., service quality, customer satisfaction and customer loyalty). Made up of structural and measurement models, SEM effectively addresses the cause-effect relations among implicit variables. Models in this study were verified in three regards: (1) whether the overall model conforms to the goodness-of-fit indicators; (2) goodness-of-fit of the 
measurement model; and (3) goodness-of-fit of the structural model.

\subsection{Test}

The questionnaire in this study didn't have the CMV problems after applying the CFA test comparison method, and the results have been shown as the Table 2 .

Table 2. CMV Test Results

\begin{tabular}{|c|c|c|c|c|c|}
\hline Model & $\chi^{2}$ & DF & $\Delta \chi^{2}$ & $\Delta \mathrm{DF}$ & $\mathrm{P}$ \\
\hline Single-Factor & 1326.2 & 97 & \multirow{2}{*}{884.8} & \multirow{2}{*}{99} & \multirow{2}{*}{0.000} \\
\cline { 1 - 2 } Multiple-Factor & 441.4 & 196 & & & \\
\hline
\end{tabular}

\section{Analyses and Results}

4.1.1.Test results regarding fit of the overall model

Table 3. Test Results Regarding Fit of the Overall Model

\begin{tabular}{|c|c|c|c|}
\hline \multicolumn{2}{|c|}{ Indicators } & Standards of Judgment & Test Results \\
\hline \multirow{3}{*}{$\begin{array}{c}\text { Measures of } \\
\text { Absolute Fit }\end{array}$} & GFI & $>0.9$ & 0.921 \\
\cline { 2 - 4 } & AGFI & $>0.8$ & 0.910 \\
\cline { 2 - 4 } & RMR & $<0.05$ & 0.012 \\
\hline $\begin{array}{c}\text { Incremental Fit } \\
\text { Measures }\end{array}$ & NFI & $>0.9$ & 0.933 \\
\cline { 2 - 4 } & CFI & $>0.9$ & 0.921 \\
\hline \multirow{2}{*}{$\begin{array}{c}\text { Parsimonious } \\
\text { Fit Measures }\end{array}$} & PNFI & $>0.5$ & 0.680 \\
\cline { 2 - 4 } & PGFI & $>0.5$ & 0.672 \\
\hline
\end{tabular}

This study built 'the overall model framework' following a literature review and a factor analysis of sample data and, as recommended by Hair, Anderson, Tatham \& Black ${ }^{12}$, measured 'the overall model's goodness-of-fit in three different ways: the Measures of Absolute Fit, the Incremental Fit Measures, and the Parsimonious Fit Measures' ${ }^{4}$. The test results listed in Table 3 show that this study established a model with good fitting degree.

\subsubsection{Measurement model}

The factor loading measures the intensity of linear correlation between each item under the manifest/explicit variables (or sub-dimensions) and latent/implicit variables (or main dimensions). The closer the factor loading is to 1 , the more capable an observable variable (or sub- dimension) is in measuring the main dimensions. This study proves reliable with an above- 0.7 factor loading in any subdimension. That is, all sub-dimensions (i.e., explicit variables) in the proposed measurement model properly measure the main dimensions (i.e., implicit variables). Meanwhile, the Average Variance Extracted (AVE) measures the unobservable/implicit variables' explanatory power of variance regarding observable ones; a higher AVE suggests greater reliability and convergent validity of an implicit variable. It usually takes an 'above- 0.5 AVE to prove a dimension's explainable variance exceeds the measurement error ${ }^{9}$. From Table 4 and Figure 2 reveal that the latent/implicit variables have excellent reliability and convergent validity as AVEs in this study invariably exceed 0.5 .

\subsubsection{Coefficient of Determination}

Also known as Squared Multiple Correlation (SMC), the Coefficient of Determination is an implicit independent variable's explanatory power regarding an implicit dependent one. That is, the $\mathrm{R}^{2}$ values shown in Table 5 indicate that the implicit independent variables have adequate explaining power on the implicit dependent variables respectively.

Table 4. Judgment Indicators for the Measurement Model

\begin{tabular}{|c|c|c|c|c|}
\hline Implicit Variables & Measurement Variables & Factor loading & Cronbach's $\alpha$ & Average Variance Extracted \\
\hline \multirow{4}{*}{ Service Quality $(\mathrm{SQ})$} & Tangibles $\left(\mathrm{SQ}_{1}\right)$ & $\mathbf{. 8 4}$ & $\mathbf{. 8 3}$ & $\mathbf{. 6 3}$ \\
\cline { 2 - 5 } & Reliability $\left(\mathrm{SQ}_{2}\right)$ & $\mathbf{. 8 3}$ & $\mathbf{. 8 2}$ & $\mathbf{. 6 2}$ \\
\cline { 2 - 5 } & Responsiveness $\left(\mathrm{SQ}_{3}\right)$ & .81 &. $\mathbf{8 0}$ & $\mathbf{. 6 1}$ \\
\cline { 2 - 5 } & Assurance $\left(\mathrm{SQ}_{4}\right)$ & $\mathbf{. 8 3}$ & $\mathbf{. 8 2}$ & $\mathbf{. 6 2}$ \\
\cline { 2 - 5 } & Empathy $\left(\mathrm{SQ}_{5}\right)$ & $\mathbf{. 8 2}$ & $\mathbf{. 8 1}$ & $\mathbf{. 6 2}$ \\
\hline \multirow{3}{*}{$\begin{array}{c}\text { Customer Satisfaction } \\
(\mathrm{CS})\end{array}$} & Product Quality $\left(\mathrm{CS}_{1}\right)$ & $\mathbf{. 8 5}$ & $\mathbf{. 8 4}$ & $\mathbf{. 6 5}$ \\
\cline { 2 - 5 } & Service Quality $\left(\mathrm{CS}_{2}\right)$ & $\mathbf{. 8 6}$ & $\mathbf{. 8 5}$ & $\mathbf{. 6 7}$ \\
\cline { 2 - 5 } & Price $\left(\mathrm{CS}_{3}\right)$ & $\mathbf{. 8 3}$ & $\mathbf{. 8 2}$ & $\mathbf{. 6 2}$ \\
\hline $\begin{array}{c}\text { Customer Loyalty } \\
(\mathrm{CL})\end{array}$ & Preference $\left(\mathrm{CL}_{1}\right)$ & $\mathbf{. 8 6}$ & $\mathbf{. 8 5}$ & $\mathbf{. 6 8}$ \\
\cline { 2 - 5 } & Repetitive Support $\left(\mathrm{CL}_{2}\right)$ & .87 & $\mathbf{8 6}$ & $\mathbf{. 6 9}$ \\
\hline
\end{tabular}

Table 5. Path Coefficient of Determination

\begin{tabular}{|c|c|}
\hline Coefficients of Determination & $\mathrm{R}^{2}$ \\
\hline Service Quality (SQ) $\rightarrow$ Customer Satisfaction (CS) & 0.63 \\
\hline Customer Satisfaction $(\mathrm{CS}) \rightarrow$ Customer Loyalty (CL) & 0.58 \\
\hline Service Quality (SQ) $\rightarrow$ Customer Loyalty (CL) & 0.33 \\
\hline
\end{tabular}


Table 6. Parameters of Latent Variables Estimation

\begin{tabular}{|c|c|c|c|c|}
\hline & Estimate & S.E. & C.R. & P \\
\hline Service Quality (SQ) $\rightarrow$ Customer Satisfaction (CS) & .581 & .102 & 5.696 & $* * *$ \\
\hline Customer Satisfaction (CS) $\rightarrow$ Customer Loyalty (CL) & .653 & .081 & 8.062 & $* * *$ \\
\hline Service Quality (SQ) $\rightarrow$ Customer Loyalty (CL) & .212 & .144 & 1.472 & \\
\hline
\end{tabular}

Remark: *** It indicates a significant C.R. Value $(\alpha=0.001)$.

Table 7. Correlation matrix

\begin{tabular}{|c|c|c|c|c|c|c|c|c|c|c|}
\hline Dimensions & $\left(\mathrm{SQ}_{1}\right)$ & $\left(\mathrm{SQ}_{2}\right)$ & $\left(\mathrm{SQ}_{3}\right)$ & $\left(\mathrm{SQ}_{4}\right)$ & $\left(\mathrm{SQ}_{5}\right)$ & $\left(\mathrm{CS}_{1}\right)$ & $\left(\mathrm{CS}_{2}\right)$ & $\left(\mathrm{CS}_{3}\right)$ & $\left(\mathrm{CL}_{1}\right)$ & $\left(\mathrm{CL}_{2}\right)$ \\
\hline$\left(\mathrm{SQ}_{1}\right)$ & 1.000 & & & & & & & & & \\
\hline$\left(\mathrm{SQ}_{2}\right)$ & $.452^{* * *}$ & 1.000 & & & & & & & & \\
\hline$\left(\mathrm{SQ}_{3}\right)$ & $.573^{* * *}$ & $.552^{* * *}$ & 1.000 & & & & & & & \\
\hline$\left(\mathrm{SQ}_{4}\right)$ & $.483^{* * *}$ & $.652^{* * *}$ & $.452^{* * *}$ & 1.000 & & & & & & \\
\hline$\left(\mathrm{SQ}_{5}\right)$ & $.563^{* * *}$ & $.483^{* * *}$ & $.571^{* * *}$ & $.331^{* * *}$ & 1.000 & & & & & \\
\hline$\left(\mathrm{CS}_{1}\right)$ & $.692^{* * *}$ & $.681^{* * *}$ & $.692^{* * *}$ & $.541^{* * *}$ & $.451^{* * *}$ & 1.000 & & & & \\
\hline$\left(\mathrm{CS}_{2}\right)$ & $.392^{* * *}$ & $.692^{* * *}$ & $.693^{* * *}$ & $.542^{* * *}$ & $.452^{* * *}$ & $.311^{* * *}$ & 1.000 & & & \\
\hline$\left(\mathrm{CS}_{3}\right)$ & $.621^{* * *}$ & $.581^{* * *}$ & $.682^{* * *}$ & $.563^{* * *}$ & $.452^{* * *}$ & $.693^{* * *}$ & $.483^{* * *}$ & 1.000 & & \\
\hline$\left(\mathrm{CL}_{1}\right)$ & .239 & .164 & $.463^{* * *}$ & .114 & .132 & $.681^{* * *}$ & $.491 * * *$ & .161 & 1.000 & \\
\hline$\left(\mathrm{CL}_{2}\right)$ & .242 & $.381^{* * *}$ & .211 & .113 & .131 & $.692^{* * *}$ & $.381^{* * *}$ & .134 & $.431^{* * *}$ & 1.000 \\
\hline
\end{tabular}

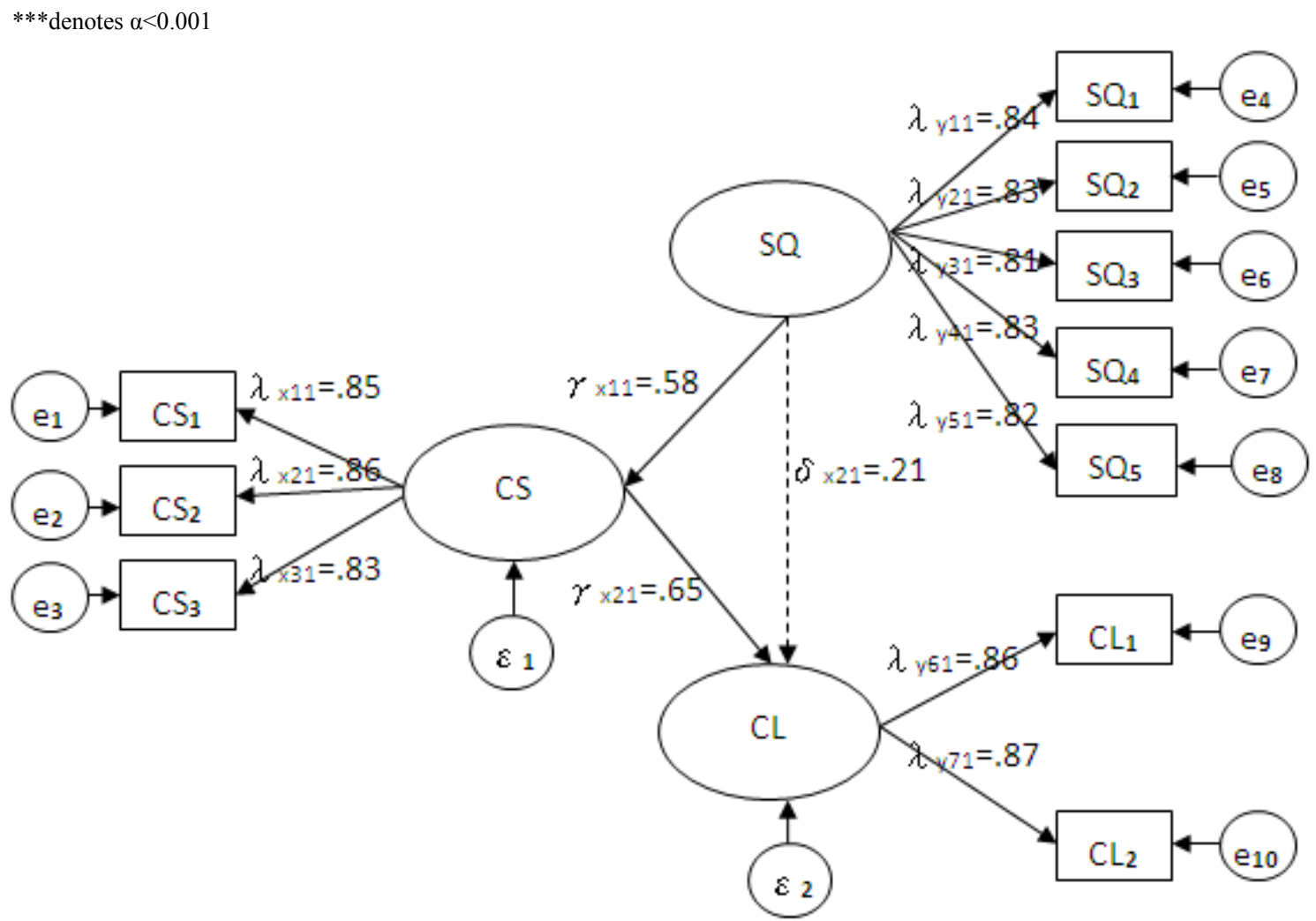

Figure 2. Standardized results of SEM analysis

4.1.4. Path coefficient of implicit variables in the model

After the model passed an internal goodness-of-fit test, the estimates of standardized path coefficients and Critical Ratio (C.R.) for latent/implicit variables, were calculated (see Table 6). Figure 2 is an illustration of the path analysis results.

\subsubsection{Correlation analysis}

The results indicate that all the correlations between factors are significant. As can be seen, the relationships between research variables are as follows:

(1)SQ is positively related to CS; (2) CS is positively related to CL; and (3) SQ is positively related to CL; as shown in Table 7. 


\subsection{Analytical Test of Path Effect for the Structural Model}

Focused on the path coefficients between implicit/unobservable variables in the structural model, this study adopted Bayesian Estimation for an analytical test to determine the structural model's path effect, with customer satisfaction (CS) as the mediator, as shown in Table 8:

(1) Service Quality (SQ) versus Customer Satisfaction (CS), Path Coefficient a1 $=0.58$, 95\% Confidence Interval $(0.500,0.662)$, significant, First-order Significant Efficacy.

(2) Customer Satisfaction (CS) versus Customer Loyalty (CL), Path Coefficient b1 $=0.65,95 \%$ Confidence Interval $(0.551,0.755)$, significant, Second-order Significant Efficacy.

(3) Service Quality (SQ) versus Customer Loyalty (CL), Path Coefficient $\mathrm{c}=0.21,95 \%$ Confidence Interval $(0.068,0.356)$, influenced but insignificant, Third-order insignificant Efficacy.

The following details were obtained from Table 9:

(1) The estimated Indirect Efficacy a $1 *$ b1 was $=0.379,95 \%$ confidence interval $(0.287,0.471)$, significant, significant indirect efficacy; the estimated proportion of indirect efficacy to total efficacy $=64.1 \%$.

(2) Due to significant indirect efficacy, direct efficacy was effective but without significant result. Therefore, "customer satisfaction" made an approximately complete mediation effect. In other words, the results have been found that (1) making positive effects on the customer satisfaction; (2) the customer satisfaction making significant and positive effects on the customer loyalty; and (3) the excellent service quality making positive but not significant effects on the customer loyalty. Based on the results, the customer satisfaction has a complete mediating effect.

From the above results, the following conclusions were made by this study:

(1) The excellent service quality of Taiwan's Watsons Personal Care Stores made positive effects on customer satisfaction; with the parameter value of standardized estimate 0.581 , the Hypothesis $\mathrm{H}_{1}$ was supported. (Hypothesis is substantiated).

(2) The customer satisfaction of Taiwan's Watsons Personal Care Stores made positive and significant effects on customer loyalty; with the parameter value of standardized estimate 0.653 , the Hypothesis $\mathrm{H}_{2}$ was supported. (Hypothesis is substantiated).

(3) The excellent service quality of Taiwan's Watsons Personal Care Stores made positive but not significant effects on customer loyalty; with the parameter value of standardized estimate 0.212 , the Hypothesis $\mathrm{H}_{3}$ was partially supported. (Hypothesis is partially substantiated).

Table 8. Bayesian Estimation

\begin{tabular}{|c|c|c|c|c|c|}
\hline Regression weights & Mean & S.D. & $\begin{array}{c}95 \% \\
\text { Lower } \\
\text { bound }\end{array}$ & $\begin{array}{c}95 \% \\
\text { Upper } \\
\text { bound }\end{array}$ & Name \\
\hline Service Quality (SQ) $\rightarrow$ Customer Satisfaction (CS) & .581 & .081 & .500 & .662 & $\mathrm{al}$ \\
\hline Customer Satisfaction (CS) $\rightarrow$ Customer Loyalty (CL) & .653 & .102 & .551 & .755 & $\mathrm{~b} 1$ \\
\hline Service Quality (SQ) $\rightarrow$ Customer Loyalty (CL) & .212 & .144 & .068 & .356 & $\mathrm{c}$ \\
\hline
\end{tabular}

Table 9. Custom estimands

\begin{tabular}{|c|c|c|c|c|}
\hline Numeric Estimands & Mean & S.D. & 95\% Lower bound & $95 \%$ Upper bound \\
\hline Direct Efficacy a1 & 0.581 & 0.081 & 0.500 & 0.662 \\
\hline Direct Efficacy b1 & 0.653 & 0.102 & 0.551 & 0.755 \\
\hline Direct Efficacy c & 0.212 & 0.144 & 0.068 & 0.356 \\
\hline Indirect Efficacy (a1*b1) & 0.379 & 0.092 & 0.287 & 0.471 \\
\hline $\begin{array}{c}\text { Total Efficacy (c+a1*b1) } \\
\text { Proportion of Indirect Efficacy to } \\
\text { Total Efficacy }\end{array}$ & 0.591 & 0.118 & 0.473 & 0.709 \\
\hline \begin{tabular}{c} 
(a) \\
\hline
\end{tabular}
\end{tabular}




\section{Conclusion and Suggestions}

According to the afore-mentioned analyses and results, this chapter specifies the conclusions and contributions of the present study. The research limitations and suggestions for future research are mentioned in the last passages.

\subsection{Conclusions}

Taking a panoramic view of previous discussion, front line employees of all Taiwan's Watsons Personal Care Stores were the objects of this study, using the SEM model to verify the effects of excellent service quality on customer loyalty - using the customer satisfaction as a mediator; herewith the study conclusion was specifically described as below:

\subsubsection{The Relevance of Service Quality Effects on Customer Satisfaction}

The Hypothesis $\mathrm{H}_{1}$ is substantiated from this study results, that is, "service quality makes positively significant effects on customer satisfaction", such a result being conformity with the opinions from the study results of Taylor \& Baker $^{35}$, Hurley \& Estelami ${ }^{15}$, Chen and Wang ${ }^{5}$, Lin $^{19}$, Huang et $\mathrm{al}^{14}$, and so on.

\subsubsection{The Relevance of Customer Satisfaction Effects on Customer Loyalty}

The Hypothesis $\mathrm{H}_{2}$ is substantiated from this study results, that is, "customer satisfaction makes positively significant effects on customer loyalty", being conformity with the opinions from the study results of $\mathrm{Lin}^{23}$, Lee and $\mathrm{Chen}^{18}$, Lin and Lee ${ }^{20}$, Huang et $\mathrm{al}^{14}$ and so on.

\subsubsection{The Relevance of Service Quality Effects on Customer Loyalty}

The Hypothesis $\mathrm{H}_{3}$ is substantiated from this study results, that is, "service quality makes positive but insignificant effects on customer loyalty", such a result being partially conformity with the opinions from the study results of Kao 17, Chen and Wang ${ }^{5}$, Chih, Chiu and Lin ${ }^{7}$; but some different opinions possibly arise from the difference of interviewed industry objects.

Generally, according to three conclusions as above, this study established a model with good fitting degree, and customer satisfaction had the "approximately complete" mediating effect. This conclusion reaches an agreement with Baron and Kenny ${ }^{1}$ thesis that "complete mediating effect" meaning a weaker or less significant relationship between independent and dependent variables after adding mediating variables.

\subsection{Research Contributions}

(1) The study results can not only provide businesses with the knowledge about the significance and generated benefits of service quality and customer satisfaction, but also make a reference for relevant business decision-making. Briefly, it is expected that the study results will provide businesses with effective applications of the service quality and customer satisfaction to enhance the customer loyalty increasing customers' repurchase intention.

(2) On the study topic of service quality effects on customer loyalty in Taiwan's Watsons Personal Care Stores used to focus on Exploratory Factor Analysis (EFA), and this study will integrate relevant study results achieved in the past to set up a modeling and verify the fit of the model; therefore, such a model can be understood whether it has excellent goodness-of-fit effects. Thus, this study's topic is one importantly practical topic of the Confirmatory Factor Analysis (CFA), which deserves more researchers to continue studying further in this field for future research references.

\subsection{Research Limitations}

This study suffers from limited resources, although it seeks to complete all the stages of research tasks in a manner as robust as possible. Below is a list of research limitations: This study adopted the Stratified Random Sampling for the sampling of the population that may result in a lower effective response rate of valid samples.

\subsection{Suggestions to Follow-up Studies}

Owing to the studies on the relevance between service quality, customer satisfaction and customer loyalty applicable to various industries, not limited to Taiwan's Watsons Personal Care Stores, additionally researchers having different definitions on service quality, customer satisfaction and customer loyalty, using different measurement indicators, therefore, only front line employees of all Taiwan's Watsons Personal Care Stores were selected to be sampling objects of this study. Future researchers can try out the effects of service quality on customer loyalty in different characteristics and industries for the purpose of a wider-range data or innovation and breakthroughs, and then, they are expected to analyze good qualities and accomplish comparisons between different industries.

\section{REFERENCES}

[1] Baron, RM, \& Kenny, DA. The moderator-mediator variable distinction in social psychological research: Conceptual, strategic, and statistical considerations. Journal of Personality and Social Psychology, 51, 1173-1182; 1986.

[2] Bhote, KR. Beyond Customer Satisfaction to Customer Loyalty-The Key to Greater Profitability. New York; 1996. 
[3] Cardozo, RN. An Experimental Study of Customer Effort, Expectation and Satisfaction. Journal of Marketing Research, 2 (3), 244-249; 1965.

[4] Chen, FC, Fang, HK, Chen, KC and Chien, AJ. A Study of Relationship on Organizational Culture, Intellectual Capital and Organizational Performance. Taiwan: Journal of Chinese Economic Research, 6, 146-168; 2008.

[5] Chen, LR and Wang, SH. A Study of Relationship among Service Quality, Customer Satisfaction and Customer Loyalty. Journal of Far East University. 23 (3), 525-536; 2006.

[6] Chen, SY. Structural Equation Modeling. Taiwan: Psychological Publishing Co., Ltd; 2010.

[7] Chih, WH, Chiu, ZQ and Lin, CY. The Relevance between Service Quality, Customer Satisfaction, Switch Cost and Customer Loyalty: An Empirical Study of Taiwan Railway. Taiwan: Journal of Commerce, Department of Business, National Open University, 16, 25-47; 2009.

[8] Chung, HJ. Study on the Relationship among Degree of Involvement, Customer Satisfaction and Loyalty: Base on the Type of Internet Shop and Customer Relationship Combination. MA Taiwan: Institute of Business Administration, Chung Yuan Christian University; 2001.

[9] Fornell. C, \& Larcker, DF. Evaluating structural equation models with un-observables and measurement error. Journal of Marketing Research, 18, 39-50; 1981.

[10] Google web: https://www.google.com.tw/webhp?hl=zh-TW

[11] Griffin, J. Customer Loyalty, Simmon \& Schuster Inc.; 1995.

[12] Hair, JF, Anderson, RE, Tatham, RL and Black, WC. Multivariate Data Analysis (5th ed.). Englewood Cliffs, NJ: Prentice-Hall; 1998.

[13] Heskett, LJ. Beyond Customer Loyalty. Managing Service Quality, 12(6), 355-357; 2002.

[14] Huang, QR, Tsai, JX, and Xu, YQ. Service Quality, Customer Satisfaction and Brand Management: A Case Study of BIONET Corp. Taiwan: Journal for SME Development, 15 (March 2010), 111-129; 2010.

[15] Hurley, RH, Estelami, H. Alternative Indexes for Monitoring Customer Perceptions Of Service Quality: A Comparative Evaluation in a Retail Context. Journal of Academy of Marketing Science, 26, (3), 209-221; 1998.

[16] Juran, JM Quality Control Handbook. New York: McGraw-Hill; 1974.

[17] Kao, CW. Relationship of Service Quality and Customer Loyalty: A Case on Eastern TV Shopping. MA Taiwan: Institute of Business Management, National Kaohsiung University of Applied Sciences; 2006.

[18] Lee, SR and Chen, ZX. Related Studies to Customer Satisfaction and Customer Loyalty under the Internet Virtual Environment. Journal of Far East University. 21(4), 625-638; 2004.

[19] Lin, CW. The study of the relationship among service quality, customer satisfaction, and customer loyalty to the hot-spring hotel-case study of Fennel Resort with hot springs.
MA Taiwan: Department of Physical Education, National Taitung University; 2010.

[20] Lin, SW and Lee, JR. The study of the relationship among Brand image, perceived value, customer satisfaction, and customer loyalty: A Case Study of Overseas Tour Packages of Travel Agencies. Tourism Management Research, 6(1), 63-81; June 2006.

[21] Lin, SE. The Study on Relationship between Customer Satisfaction and Customer Loyalty: As Applied to a Certification Company. MA Taiwan: Department of Industrial Engineering, Chung Yuan Christian University; 2003.

[22] Lin, YC. The determinant model and effects of customer satisfaction for automobile in the Taiwan area: an empirical study. Ph.D. Taiwan: Graduate Institute of Business Administration, National Taiwan University; 1996.

[23] Lu, NH. Consumer Behavior (First Edition), Taipei: Huali Books Ltd; 2006.

[24] Michael, DJ. Improving Customer Satisfaction, loyalty, and profit: an integrated measurement and management system. Jossey-Bass, Inc. a John Wiley and Sons, Inc; 2002.

[25] Oliver, LR. Satisfaction: A Behavioral Perspective on the Consumer, New York: Irwin/McGraw-Hill; 1997.

[26] Oliver, RL. Measurement and Evaluation of Satisfaction Processes in Retailing Setting. Journal of Retailing, 57 (3), 25-48; 1981.

[27] Oliver, RL. Whence Consumer Loyalty? Journal of Marketing, 63 (63), 33-44; 1999.

[28] Ostrom, A, Iacobucci, D. Consumer Trade-Offs and the Evaluation of Services. Journal of Marketing, 59 (1), 17-28; 1995.

[29] Parasuraman, A, Zeithaml, V., Berry, L. Understanding Customer Expectations of Service. Sloan Management Review, Spring, 39-48; 1991.

[30] Parasuraman, A, Zeithaml, V, \& Berry, L. A Conceptual Model of Service Quality and Its Implications for Future Research. Journal of Marketing, 49, 41-45; 1985.

[31] Parasuraman, A, Zeithaml, V, Berry, L. SERVQUAL: A Multi-item Scale for Measuring Consumer Perceptions of Service Quality. Journal of Retailing, 64 (1), 12- 37; 1988

[32] Singh, J. Understanding the Structure of Consumers' Satisfaction Evaluation of Service Delivery. Journal of the Academy of Marketing Science, 19 (3), 223-234; 1991.

[33] Sirdeshmukh, D, Sabol, B. Consumer Trust, Value, and Loyalty in Relational Exchanges. Journal of Marketing, 66, $15-37 ; 2002$.

[34] Spreng, RA. A Comprehensive Model of the Consumer Satisfaction Formation Process. Dissertation Abstracts International, 53 (7), 2461-2462; 1993.

[35] Taylor, SA, Baker, TL. An assessment of the relationship between service quality and customer satisfaction in the formation of consumers' purchase intentions. Journal of Retailing, 70, 163-178; 1994.

[36] Watsons web: http://www.watsons.com.tw/company; 2015. 
[37] Westbrook, RA. Sources of Consumer Satisfaction with Retail Outlets. Journal of Retailing, 57 (Fall), 68-85; 1981.

[38] Wiley, JW. Customer satisfaction: A supportive work environment and its financial cost. Human Resource Planning, 14(2), 117-127; 1991.

[39] Wirtz, J, Bateson, EG. An Experimental Investigation of Halo Effects in Satisfaction Measures of Service Attributes,
International Journal of Service Industry Management, 6, 84-102; 1995.

[40] Zeithaml, VA, Binter, MJ. Service Marketing, NY: McGraw Hill; 1996.

[41] Zeng, GH. Marketing Management: Theoretical Analyses and Practices (First Edition). Taiwan: Future (Qian-Cheng) Management Consulting Firm Exclusive Distribution; 2004. 